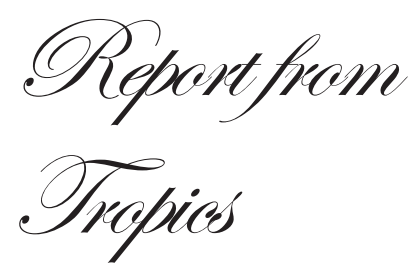

Tropical Medicine Department,
Faculty of Medicine, Zagazig
University,
Zagazig, 44519, Egypt
Correspondence:
Dr. Mohammad Hassan Emara
Email: emara 20007@yahoo.com

Email: emara20007@yahoo.com

\section{Occult hepatitis B: the Egyptian situation}

\author{
Mohammad Hassan Emara
}

\section{ABSTRACT}

Occult hepatitis B infection is defined as the presence of HBV DNA in serum and/or the liver tissue without detectable HBsAg with or without anti-HBc or anti-HBs antibodies. In Egypt many studies on occult hepatitis B have been conducted and this infection is well established in various patients groups. This short review sheds light on the occurrence of occult hepatitis B infection among different disease states in Egypt. The coexistence of occult hepatitis B with hepatitis $\mathrm{C}$ infection is of particular importance because of its added co-morbidity of liver enzymes elevation, increased severity of liver disease and increased risk of hepatocellular carcinoma. Patients on regular hemodialysis and those exposed to blood transfusion are at high risk of acquiring this form of infection. The highest prevalence of occult hepatitis B virus in Egypt was reported among patients with hepatocellular carcinoma and similar to the scenario for classic hepatitis B infection, genotype D is the most prevalent genotype.

KEYWORDS: occult hepatitis B, hepatitis C, pegylated interferon, hepatocellular carcinoma

\title{
Introduction
}

Hepatitis B virus (HBV) infection is a global health problem. Its prevalence and patterns of transmission vary greatly throughout the world. ${ }^{1}$ Furthermore, the consequences of chronic HBV infection represent a major burden for health care systems because a large proportion of these patients go on to develop cirrhosis and hepatocellular carcinoma (HCC). ${ }^{2}$ The prevalence of HBsAg in Egypt is of intermediate endemicity (2-8\%). ${ }^{3}$ Nearly 2-3 million Egyptians are chronic carriers of $\mathrm{HBV}$. In Egypt HBV transmission is apparently a mixture of horizontal and perinatal transmission. However, the majority of $\mathrm{HBV}$ infection is acquired by the former route. ${ }^{2}$

Occult hepatitis B virus infection (OBI) is one of the most challenging topics in the field of viral hepatitis with its virological and clinical relevance being debated for more than
30 years. ${ }^{4}$ Occult hepatitis B virus infection is defined as the presence of HBV DNA in serum and/or liver tissue without detectable HBsAg with or without anti-HBc or anti-HBs antibodies outside the pre-seroconversion window period. ${ }^{5}$

Prevalence of OBI varies in different studies due to differences in: (1) method of detection, including PCR primer selection and sensitivity of the assay; (2) patient recruitment, for example blood donors with/without anti-HBc; (3) patients from countries highly endemic for $\mathrm{HBV}$ are more likely to develop OBI; (4) prevalence may vary according to the nature of the biological material tested, with a higher proportion for liver compared to serum specimens and also the amount of DNA in the tested sample may influence prevalence rates of $\mathrm{OBI} ;{ }^{6}$ and (5) a spurious increase of $\mathrm{OBI}$ prevalence rates may 
also noticed when kits with low sensitivity for detection of $\mathrm{HBsAg}$ are used. Hence to correctly test for $\mathrm{HBsAg}$, international standard samples with known quantities of $\mathrm{HBsAg}$ are required. ${ }^{7}$

Since the diagnosis of OBI is dependent on detection of HBV DNA by PCR, which is an expensive tool and the Egyptian budget for health care and scientific research is very low, many Egyptian studies depend on anti-HBc positivity for diagnosis of OBI leading to missing of HBV DNA positive/anti-HBc negative cases and consequently underestimating the problem.

Although there are no accurate estimates about the prevalence of OBI in different population groups in Egypt, this review is an attempt to shed light on available studies examining OBI prevalence and its impact on different population groups in Egypt (Table 1).

\section{OBI and genetic mutations}

Replication-defective mutants of HBV have been detected in the circulation of symptom free individuals as early as $1987 .{ }^{8}$ In $\mathrm{HBV}$ sequences obtained from serum samples of HBsAg seronegative carriers, a plethora of mutations has been observed. Point mutations, deletions and splicing alternatives have been associated with OBI, but it is unclear weather these

Table 1: Occult hepatitis B studies from Egypt

\begin{tabular}{|c|c|c|c|c|c|}
\hline Author & Year & $\begin{array}{l}\text { Diagnosis of } \\
\text { OBI }\end{array}$ & Target population & $\begin{array}{l}\text { OBI } \\
\text { prevalence } \\
(\%)\end{array}$ & Comments \\
\hline$\overline{\text { El-Shaarawy et al. }{ }^{23}}$ & 2007 & Anti-HBc & $\begin{array}{l}40 \text { patients with } \\
\text { HCV related liver } \\
\text { disease }\end{array}$ & 50 & $\begin{array}{l}\text { Comparable severity of liver disease in Anti-HBc } \\
\text { positive/ HBV DNA positive and Anti-HBc positive } \\
\text { /HBV DNA negative cases }\end{array}$ \\
\hline El-Sherif et al. ${ }^{19}$ & 2009 & $\begin{array}{l}\text { Anti-HBc/ } \\
\text { DNA }\end{array}$ & $\begin{array}{l}71 \text { patients with } \\
\mathrm{HCV} \text { positive for } \\
\text { anti-HBc } \\
29 \text { patients with } \\
\mathrm{HCV} \text { negative for } \\
\text { anti-HBc }\end{array}$ & 22.5 & $\mathrm{OBI}$ is prevalent in $\mathrm{HCV}$ positive for Anti-HBc \\
\hline Said et al..$^{59}$ & 2009 & DNA & $\begin{array}{l}49 \text { child with } \\
\text { haematological } \\
\text { disorders } \\
51 \text { child with } \\
\text { haematological } \\
\text { malignancies }\end{array}$ & 38 & $\begin{array}{l}\text { OBI and HCV are common in multi-transfused } \\
\text { immunocompromised children }\end{array}$ \\
\hline Ismail et al. ${ }^{60}$ & 2010 & DNA & $\begin{array}{l}64 \text { chronic } \\
\text { haemodialysis } \\
\text { HCV RNA positive } \\
\text { patients } \\
52 \text { chronic } \\
\text { haemodialysis } \\
\text { HCV RNA negative } \\
\text { patients }\end{array}$ & 3.8 & $\begin{array}{l}\text { OBI in chronic hemodialysis patients is low, and } \\
\text { does not significantly differ between patients with or } \\
\text { without HCV }\end{array}$ \\
\hline Emara et al. ${ }^{48}$ & 2010 & DNA & $\begin{array}{l}156 \mathrm{HCV} \text { infected } \\
\text { patients under } \\
\text { Pegylated interferon } \\
\text { therapy }\end{array}$ & 3.9 & No impact on therapy \\
\hline Hassan et al. ${ }^{24}$ & 2010 & DNA & $\begin{array}{l}40 \text { HCC patients: } \\
\text { Tissue } \\
\text { Serum }\end{array}$ & 62.5 & $\begin{array}{l}\text { In } \mathrm{HCC}-\mathrm{OBI} \text { more in tissue than serumGenotype B } \\
\text { and } \mathrm{D} \text { are the prevalent genotypes }\end{array}$ \\
\hline Selim et al. ${ }^{25}$ & 2011 & DNA & $\begin{array}{l}30 \mathrm{HCV} \text { with liver } \\
\text { enzymes flare } 30 \mathrm{HCV} \\
\text { with no liver enzymes } \\
\text { flare }\end{array}$ & & $\begin{array}{l}\text { OBI should be considered in HCV with enzymes } \\
\text { flare }\end{array}$ \\
\hline $\begin{array}{l}\text { Abu El-Makarem } \\
\text { et al. }{ }^{51}\end{array}$ & 2012 & DNA & $\begin{array}{l}145 \text { hemodialysis } \\
\text { patients with } \\
\text { negative HbsAg }\end{array}$ & 4.1 & $\begin{array}{l}\text { OBI in chronic hemodialysis patients does not } \\
\text { significantly differ between patients with or without } \\
\text { HCV }\end{array}$ \\
\hline
\end{tabular}


mutations are a cause or a consequence of this occult infection. Many of these OBI are associated with mutations in the $\mathrm{S}$ gene and/or regions governing the regulation of $\mathrm{S}$ gene expression, but they have also been documented in the core $(\mathrm{C})$ and polymerase (P) genes. ${ }^{9}$ Naturally occurring pre-S deletion mutants were shown to influence not only the liver disease progression but also chronic hepatitis B therapy. Mutations that change the antigenicity of $\mathrm{HBsAg}$ or decreases its synthesis may be the cause of lack detection of HBsAg in patients with OBI. ${ }^{10}$

It was shown that OBI individuals are infected by viral variants either producing an antigenically modified HBV S protein undetectable by the available HBsAg assays, ${ }^{11}$ or carrying mutations capable of inhibiting $\mathrm{S}$ gene expression and/or viral replication. ${ }^{12}$ Pre-S variants and deletions were also found in occult isolates. One study showed that deleted regions were found more frequently in the 3 ' terminus of pre-S1 which contains several immune epitopes and functional domains such as the site for dual topology, a nucleocapsid binding site, and the S-promote. ${ }^{13}$ Removing sites for dual topology and encapsidation would lead to incorrect conformation of the large $\mathrm{HBsAg}$ and decrease secretion of HBsAg and viral particles. ${ }^{14}$ Another important consequence of the deletion is that removing the $\mathrm{S}$ promoter alters small HBsAg expression and leads to $\mathrm{HBsAg}$ seronegativity. ${ }^{15}$ Chaudhuri et $\mathrm{al}^{12}$ found a similar pre-S variant from occult HBV carriers and demonstrated that deletion of the $\mathrm{S}$ promoter alters the ratio of large and small surface proteins and decreases the circulating HBsAg level. Therefore, the existence of HBsAgnegative $\mathrm{HBV}$ infection may result from deletion of the $\mathrm{S}$ promoter in the pre-S region, thus decreasing the quantity of HBsAg secretion below the sensitivity of a standard test but just enough for viral assembly. ${ }^{10}$

\section{Co-infection with hepatitis $\mathrm{C}$ virus (HCV)}

In Egypt the rate of anti-HCV positivity is $15 \%$ (although ranges from $6-28 \%$ are proposed) and 5\% of community is positive for both anti-HCV and $\mathrm{HBsAg}$ and/or anti-HBc, although the real estimated prevalence of $\mathrm{HBV} / \mathrm{HCV}$ dual infection is unclear. ${ }^{16}$ DNA positive OBI was evaluated in Egyptian chronic $\mathrm{HCV}$ patients on pegylated interferon/ribavirin therapy and was noted to occur at a rate of $3.9 \%,{ }^{17}$ this rate is increased to $10 \%$ in the subgroup of patients who developed elevated liver enzymes while on therapy, ${ }^{18}$ and the rate increased to $20 \%$ in the subgroup of patients who had elevated liver enzymes without therapy. ${ }^{19}$ The prevalence of OBI in chronic HCV patients was higher in subjects having either anti-HBs or anti$\mathrm{HBc}$ or both. ${ }^{20,21}$ Serological findings in patients with OBI and $\mathrm{HCV}$ co-infection revealed that $35 \%$ of people were anti-HBs positive, $42 \%$ were anti-HBc IgG positive and $22 \%$ were negative for both. ${ }^{22}$

In one study from Egypt, the prevalence of OBI in chronic $\mathrm{HCV}$ was projected to be $50 \%$ depending on anti-HBc positivity only, although only $60 \%$ of these tested positive for HBV DNA by PCR. ${ }^{23}$ This is not in agreement with the consensus of HBV DNA positivity as a prerequisite for diagnosis of $\mathrm{OBI} .{ }^{24} \mathrm{In}$ another study on Egyptian chronic HCV patients, serum HBV DNA was detected in $22.5 \%$ of anti-HBc positive chronic $\mathrm{HCV}$ patients and nothing was detected in anti-HBc-negative chronic HCV patients. ${ }^{21}$ In another study OBI was detected in 19 patients with $\mathrm{HCV}$ infection (out of 40), it was higher in patients positive for both anti-HBs and anti-HBc (50\%) than those having anti-HBc alone $(20 \%) .{ }^{24}$ Although this was not the observed trend in other studies. ${ }^{18,25}$ Emara et al ${ }^{18}$ examined 155 chronic $\mathrm{HCV}$ patients on pegylated interferon/ribavirin combination and found six patients positive for HBV DNA. OBI could not be predicted by serological markers of HBV infection because only two out of the six patients with detectable HBV DNA had anti-HBc antibodies and none had anti-HBs antibodies. ${ }^{18}$ While one study did not notice and variation in the prevalence of occult HBV infection with age or sex, ${ }^{24}$ another study found $\mathrm{OBI}$ prevalence higher in younger chronic $\mathrm{HCV}$ patients. $^{18}$

\section{OBI/HCV viral interference}

Preliminary data suggest that $\mathrm{HCV}$ core protein might inhibit the replication of $\mathrm{HBV} .{ }^{26} \mathrm{~A}$ similar effect was also attributed to NS2 protein of $\mathrm{HCV}^{27}$ Hepatitis $\mathrm{C}$ infection reduces the expression of $\mathrm{HBV}$ proteins in the liver. ${ }^{28}$ Conversely, there is some evidence that $\mathrm{HBV}$ replication might interfere with $\mathrm{HCV}$ viral load $^{29}$ and even lead to a higher chance of HCV RNA clearance. ${ }^{30}$ Both events have been demonstrated in the study of Rodriguez-Inigo et $\mathrm{al}^{31}$ where they proved that both $\mathrm{HCV}$ and HBV can coexist in the same hepatocyte. Furthermore, HBV DNA levels in co-infected hepatocytes were lower than those in cells infected only with HBV. This finding supports the hypothesis of inhibition of $\mathrm{HBV}$ replication by HCV. Also, HCV RNA levels were lower in co-infected cells than in cells infected with HCV only, suggesting that HBV may also inhibit $\mathrm{HCV}$ replication. However, it seems that inhibition of $\mathrm{HBV}$ 
replication by $\mathrm{HCV}$ is more common than the opposite.

Co-infection by both occult hepatitis B and occult hepatitis $\mathrm{C}$ does occur and contrary to the fact that dual chronic HBV and HCV leads to a more severe disease than mono-infection ${ }^{32}$ dual occult infection was not associated with more severe liver disease in comparison to single occult mono-infection. This data suggests that in occult infections both viruses tend to inhibit each other reciprocally. This can be explained by: (1) in chronic dual infection, a more vigorous immune response against the infected hepatocytes is the cause of severe liver damage, (2) in occult infection antigen expression on infected hepatocytes may be too low to trigger sufficient cytopathic antiviral immune response so as to induce a greater liver damage in occult dual infection compared to a single occult infection and dual chronic infections. ${ }^{33}$

\section{Impact of OBI on HCV disease states}

Flares of liver enzymes

Several investigators have studied the association between OBI and increased liver enzymes in serial serum samples. Zignego et $\mathrm{al}^{34}$ found that ALT relapses following interferon treatment for chronic HCV were associated with HBV viremia in some cases. Fujiwara et $\mathrm{al}^{35}$ found that $\mathrm{HBV}$ viremia in chronic $\mathrm{HCV}$ patients with OBI did not correlate with liver enzyme flares. Kannangai et $\mathrm{al}^{36}$ demonstrated that episodes of viremia in $\mathrm{OBI} / \mathrm{HCV}$ dually infected non-treated intravenous drug users can be associated with transient but significant flares in liver transaminases. This notion supports the hypothesis that OBI replication may be a cause of hepatocyte injury, although this is contrary to the trend in literature about the lack of strong correlation between ALT/AST levels and OBI in cross sectional studies. $^{37,38}$

The ALT levels are usually mildly raised in OBI and HCV co-infection ${ }^{20,39}$ and seem to be either equivalent ${ }^{40}$ or mildly raised $^{19,20,41}$ than in HCV mono-infection. The effect of OBI on liver enzyme flares has not been studied extensively in the Egyptian literature. One study found that OBI is not a cause of liver enzyme flare during pegylated interferon/ribavirin therapy for chronic HCV. ${ }^{19}$ Another recent Egyptian study compared the frequency of OBI in chronic HCV with normal or slightly raised liver enzymes with another group of patients with liver enzyme flare (>5 folds) and found OBI in $63.3 \%$ of patients with enzymes flare in comparison to $13.3 \%$ in the normal enzymes group. ${ }^{25}$
Increased severity of liver disease

In a surprising contrast to the mild inflammation noticed in $\mathrm{OBI} / \mathrm{HCV}$ co-infection ${ }^{42}$ most studies have demonstrated an increased prevalence of advanced fibrosis/cirrhosis in these cases. ${ }^{41-43}$ Such occult HBV co-infection is associated with more severe liver disease and higher HCV viral load. ${ }^{44}$ In one study from Egypt the presence of OBI was found to aggravate the severity and deterioration of liver disease in patients with chronic HCV. ${ }^{45}$ In contrast other studies found no association between OBI and the degree of liver necroinflammation and fibrosis. ${ }^{37,46}$ In agreement with these latter findings is our study where we found less hepatic fibrosis in OBI/HCV co-infected patients in comparison to $\mathrm{HCV}$ mono-infections. Necroinflmmatory activity also showed no significant difference, although these results may be due to the small number of patients in the co-infection group of our study. ${ }^{17}$

\section{Altered response to antiviral treatment}

Some studies suggest a negative influence of OBI on the response to standard interferon therapy in chronic $\mathrm{HCV}$ infection irrespective of HCV genotypes ${ }^{20,43,44,47,48}$ but this observation needs to be confirmed in $\mathrm{HCV}$ populations treated with the current gold standard, pegylated-interferon/ribavirin combination therapy. ${ }^{4}$ Consequently we conducted a cross sectional study to evaluate the prevalence and impact of OBI in $\mathrm{HCV}$ patients on antiviral therapy. Out of the $155 \mathrm{HCV}$ patients under treatment, six were HBV DNA positive (OBI) and there was no statistically significant difference in response to $\mathrm{HCV}$ treatment with pegylated interferon/ribavirin combination therapy. ${ }^{17}$

\section{Increased risk of $\mathrm{HCC}$}

There is an elevated risk of $\mathrm{HCC}$ in $\mathrm{HCV}$ patients because this silent infection can affect the progression of liver disease towards HCC development. ${ }^{49}$ Studies have found high proportion of $\mathrm{HCV}$ related $\mathrm{HCC}$ patients suffering from concomitant $\mathrm{OBI}^{50}$

\section{Anti-HBc antibody and $\mathrm{HCV}$}

Advanced hepatic fibrosis has been reported in patients with isolated anti-HBc and chronic HCV infection. ${ }^{47}$ Anti-HBc 
antibody was linked to more severe liver disease and poor response rates to interferon therapy for $\mathrm{HCV}$ in international ${ }^{29}$ and Egyptian studies alike. . $^{\text {2,21,51 }}$

\section{Occult hepatitis B and blood transfusion}

The first recorded evidence of OBI and possible transmission occurred via blood transfusion. ${ }^{52}$ This was further confirmed in the chimpanzee model when cloned full-length HBV-DNA from patients with OBI was confirmed to be infectious and generated a typical HBV infection. ${ }^{53}$ Thus HBsAg non-reactive blood donations containing HBV DNA have to be considered infectious. ${ }^{54}$ In Egypt prevalence of anti-HBc antibody in HBsAg negative blood donors was found to be $13.3 \%$ of which $10 \%$ were HBV DNA positive. ${ }^{55}$ In another large Egyptian study among the accepted blood units for donation in blood banks, anti-HBc antibody was found in 78/712 units (10.96\%). HBV DNA was detected in 9/78 (11.54\%) of the anti-HBc-positive units and thus OBI was detected in $9 / 712(1.26 \%)$ of the accepted blood donations. Implementing anti-HBc test to the routine assay for the forthcoming two decades would certainly eliminate the possibly HBV-infected units. Rejection of these units will be beneficial to decrease the risk of $\mathrm{HBV}$ transmission with its potential consequences particularly in immunocompromised recipients. ${ }^{56}$ The prevalence of OBI is much higher in patients exposed to multiple blood transfusions ${ }^{57}$ especially when immunocompromised. ${ }^{58}$ OBI was reported in $21 \%$ of Egyptian HCV infected children with hematological disorders and malignancies. ${ }^{59}$

\section{Occult hepatitis B and hemodialysis}

$\mathrm{HBV}$ and $\mathrm{HCV}$ share common routes of transmission and hence patients on hemodialysis are at increased risk of exposure to infected blood and instruments and acquiring both infections. In one study from upper Egypt $4 \%$ of hemodialysis patients were found to have OBI. The prevalence did not significantly vary between hemodialysis patients with or without HCV coinfection. ${ }^{51}$ Another study from lower Egypt reported lower prevalence of OBI in chronic hemodialysis patients and there was no significant difference in prevalence between hemodialysis patients with $(6.3 \%)$ or without $(3.8 \%) \mathrm{HCV}$ coinfection. ${ }^{60}$

\section{Risk of $\mathrm{HBV}$ reactivation}

Any patient with OBI receiving systemic chemo- radio- or immuno-therapy is potentially at risk of $\mathrm{HBV}$ reactivation, ${ }^{6}$ leading to the development of a typical hepatitis B infection that often has a severe and sometimes even fulminant clinical course. ${ }^{61}$ The risk of reactivation is well documented in $\mathrm{HBsAg}$ positive hemato-oncologic patients who require pre-emptive antiviral therapy. All patients receiving chemo- and immunotherapy should be tested at least once for anti-HBc antibodies before starting therapy and monitored periodically for ALT elevations. In case of ALT elevation, further diagnostic workup is required pending initiation of antiviral therapy upon establishing the diagnosis of HBV reactivation. ${ }^{62}$ In this context OBI patients under immunosuppression may show a reactivation of viral replication when immunological reconstitution is achieved with a subsequent cytotoxic $\mathrm{T}$ lymphocyte mediated hepatocyte injury. ${ }^{63}$ Monitoring in such cases should be extended for months or even years after discontinuation of immunosuppression. ${ }^{64}$ Patients prone to OBI reactivation are shown in Table 2.

Table 2: Categories of occult HBV carriers known to be prone to viral reactivation

Patients with

- Haematological malignances

- HIV infection

Patients who have undergone

- Bone marrow transplantation

- Liver transplantation

- Renal transplantation

- Chemotherapy

- Treatment with anti-CD20 (Rituximab)

- Treatment with anti-CD52 (Alemtuzumab)

- Treatment with anti-TNF- $\alpha$ (Infliximab)

\section{OBI and organ transplantation}

Transmission and reactivation of OBI is important in the setting of organ transplantation particularly with liver transplants. There is a risk of transmission of OBI through an orthotopic liver transplant from an OBI-seropositive (anti-HBc-positive) donor, in particular if the recipient is negative for all HBV serum markers, because of the presence of viral strains in the hepatocytes which can be reactivated during immunosuppression. ${ }^{65}$ Prophylaxis with antiviral agents such as lamivudine prevents hepatitis B of the recipient in most (but not all) of these cases. ${ }^{66}$ Although theoretically possible, there is no evidence of $\mathrm{HBV}$ transmission from occult HBVseronegative organ donors. ${ }^{63}$ In immunocompetent recipients there is no evidence that anti-HBs containing components are infectious, even at low titers. ${ }^{54}$ The risk of occult HBV 
transmission is very low after kidney, heart or bone marrow transplant. ${ }^{67}$ Although the risk of acquiring HBV infection after bone marrow transplantation is low, nevertheless, reactivation of the latent infection may sometimes occur and lead to fulminant hepatic failure (FHF). A case of FHF due to HBV was reported 22 months after bone marrow transplantation obtained from patient found to be anti-HBs positive, HBsAg negative and only positive for intrahepatic HBV DNA prior to transplantation. ${ }^{68}$

\section{Occult hepatitis B and hepatocellular carcinoma}

HCC patients living in areas endemic for HBV were frequently found positive for $\mathrm{HBsAg}$ and/or anti-HBc antibodies and this strong relationship was the first epidemiological evidence of HBV-related oncogenic transformation. ${ }^{69}$ Persistent HBV infection may have a critical role in development of $\mathrm{HCC}$ even in HBsAg-negative patients. ${ }^{24}$ Development of HCC in OBI patients seems to be related in most cases to the associated co-infection with HCV and to the presence of cirrhosis, although OBI mono-infection still bears an oncogenic potential. ${ }^{24,50}$ The highest prevalence of OBI in Egypt was reported among patients with $\mathrm{HCC} .{ }^{24,50} \mathrm{~A}$ difference in OBI prevalence rates as per the biological matter tested, is reflected in an Egyptian study where intrahepatic occult HBV DNA was detected in $62.5 \%$ cases, whereas serum occult HBV DNA was detected in only $22.5 \%$ of the same HCC patient group. ${ }^{24}$

OBI could accelerate the evolution to cirrhosis in $\mathrm{HCV}$ patients, ${ }^{43}$ and cirrhosis is known to be the most important risk factor for the development of HCC. ${ }^{37}$ The cryptic infection appears to exert its pro-oncogenic role in $\mathrm{HCV}$ infected patients as well as in alcoholics and in individuals with cryptogenic liver disease. ${ }^{64,70}$ In HCV-related HCC the prevalence of serum OBI was $47.4 \%$ (9/19). The prevalence of OBI was higher in patients with both anti-HBs and anti-HBc 2/4 (50\%) antibodies than those with anti-HBc alone $1 / 5(20 \%) .{ }^{24}$ One of the markers expressed in HBsAg negative $\mathrm{HCC}$ cases is the expression of the HBV-X gene. Several studies ${ }^{71-74}$ have reported the HBV-X protein in the malignant liver tissues. The $\mathrm{X}$ gene deregulates cell cycle control, interferes with cellular DNA repair and apoptosis and plays an important role in interaction with p53 and Rb gene. ${ }^{71}$ One Egyptian study found that HBV DNA and HBV-X gene was positive in 24/42 $(57.1 \%)$ cases of HCC patients, candidates for liver resection, $\mathrm{HBV}-\mathrm{X}$ gene expression was significantly higher in HCC patients than in the HCV infected group. ${ }^{64}$

\section{OBI and chronic liver disease}

Occult HBV has been associated with more advanced fibrosis/ cirrhosis. ${ }^{21}$ About $72 \%$ of HCC patients with intrahepatic occult HBV had cirrhosis. Cirrhosis is considered an important risk factor for the development of HCC. ${ }^{20}$ Similarly it was found that HBV mixed genotype infections could probably be of clinical significance in $\mathrm{HBV}$-induced liver diseases. Prevalence of mixed genotype infections was found to be $15.7 \%$ especially in those with chronic active hepatitis. ${ }^{49}$ One Egyptian study observed that anti-HBc positive/HBV-DNA negative patients showed a similar prevalence of severe liver disease to anti$\mathrm{HBc}$ positive/HBV-DNA positive patients and a significantly higher prevalence than anti-HBc negative cases. This notion raises the clinical significance of isolated positive anti-HBc antibody in relation to liver disease, ${ }^{23}$ although in other studies no association was found between OBI and the degree of liver necroinflammation and fibrosis. ${ }^{37,46}$

\section{Genotypes}

HBV genotype D is the prevalent genotype among chronic HBV infection in Egypt. ${ }^{2}$ In one Egyptian study on the role of $\mathrm{OBI}$ in $\mathrm{HCC}$, intrahepatic $\mathrm{HBV}$ infections were attributed predominantly to viral genotypes $\mathrm{D}$ and $\mathrm{B}$ that constituted 8/ $25(32 \%)$ and $6 / 25(24 \%)$ of cases, respectively. HBV genotypes $\mathrm{A}$ and $\mathrm{C}$ infections were the least observed and constituted $4 \%$ and $8 \%$ of the cases, respectively, compared to $100 \%$ of $\mathrm{HBV}$ genotype A and D mixed infections in the control group (HBsAg positive HCC patients) with no other genotypes observed. In addition, there was a relatively high prevalence of mixed infections of 5/25 (20\%) among the studied group. One case had both genotypes A and D, two cases had both B and D and two cases had genotypes B and C. No HBV genotype $\mathrm{E}$ or $\mathrm{F}$ was found in this study and furthermore, genotypes $\mathrm{G}$ and $\mathrm{H}$ were not determined. ${ }^{24}$

\section{Acknowledgements}

The author would like to thank Professor Amira Soliman for revising this work.

\section{References}

1. Margolis HS, Alter MJ, Hadler S. Viral hepatitis. In: Evans AS, Kaslow RA, eds. Viral infections of humans: Epidemiology and 
control. 4th ed. Springer, 1997:363-418.

2. El-Zayadi A. Hepatitis B virus infection: The Egyptian situation. Arab J Gastroenterol. 2007;8(3):94-98.

3. Attia MA. Prevalence of hepatitis B and C in Egypt and Africa. Antivir Ther. 1998;3:1-9.

4. Raimondo G, Allain JP, Brunetto MR, Buendia MA, Chen DS, Colombo M, et al. Statements from the Taormina expert meeting on occult hepatitis B virus infection. J Hepatol. 2008;49:652-7.

5. Brechot C, Thiers V, Kremsdorf D, Nalpas B, Pol S and PaterliniBrechot P. Persistent hepatitis B virus infection in subjects without hepatitis B surface antigen: clinically significant or purely "occult"? Hepatology. 2001;34:194-203.

6. Chemin I and Trepo C. Clinical impact of occult HBV infections. J Clin Virol. 2005;34 Suppl 1:S15-21.

7. Ocana S, Casas ML, Buhigas I and Lledo JL. Diagnostic strategy for occult hepatitis B virus infection. World J Gastroenterol. 2011;17:1553-7.

8. Okamoto $\mathrm{H}$, Tsuda $\mathrm{F}$ and Mayumi M. Defective mutants of hepatitis B virus in the circulation of symptom-free carriers. Jpn J Exp Med. 1987;57:217-21.

9. Cabrerizo M, Bartolome J, Caramelo C, Barril G and Carreno V. Molecular analysis of hepatitis B virus DNA in serum and peripheral blood mononuclear cells from hepatitis B surface antigen-negative cases. Hepatology. 2000;32:116-23.

10. Chen BF. Clinical significance of the hepatitis B virus pre-S deletion. FJJM. 2010;8:85-95.

11. Gerlich WH, Glebe D and Schuttler CG. Deficiencies in the standardization and sensitivity of diagnostic tests for hepatitis B virus. J Viral Hepat. 2007;14 Suppl 1:16-21.

12. Chaudhuri V, Tayal R, Nayak B, Acharya SK and Panda SK. Occult hepatitis B virus infection in chronic liver disease: fulllength genome and analysis of mutant surface promoter. Gastroenterology. 2004;127:1356-71.

13. Mu SC, Lin YM, Jow GM and Chen BF. Occult hepatitis B virus infection in hepatitis B vaccinated children in Taiwan. $J$ Hepatol. 2009;50:264-72.

14. Poisson F, Severac A, Hourioux C, Goudeau A and Roingeard P. Both pre-S1 and S domains of hepatitis B virus envelope proteins interact with the core particle. Virology. 1997;228:115-20.

15. Bock CT, Kubicka S, Manns MP and Trautwein C. Two control elements in the hepatitis B virus S-promoter are important for full promoter activity mediated by CCAAT-binding factor. Hepatology. 1999;29:1236-47.

16. el-Sayed HF, Abaza SM, Mehanna S and Winch PJ. The prevalence of hepatitis B and C infections among immigrants to a newly reclaimed area endemic for Schistosoma mansoni in Sinai, Egypt. Acta Trop. 1997;68:229-37.

17. Emara MH, El-Gammal NE, Mohamed LA and Bahgat MM. Occult hepatitis B infection in egyptian chronic hepatitis C patients: prevalence, impact on pegylated interferon/ribavirin therapy. Virol J. 2010;7:324.

18. El-Gammal N, Mohamed L, Bahgat M, Elhawari S, Emara M. Occult hepatitis $\mathrm{B}$ and liver enzymes elevation during pegylated interferon/Ribavirin therapy in Egyptian chronic hepatitis C patient. Gut. 2010;59(Suppl III):A429.

19. El-sherif WT, Sayed SK, Afifi NA, EL-Amin HA. Occult Hepatitis B Infection among Egyptian Chronic Hepatitis C
Patients and its Relation with Liver Enzymes and Hepatitis B Markers. Life Sci J. 2012;9(2):467-74.

20. Fukuda R, Ishimura N, Niigaki M, Hamamoto S, Satoh S, Tanaka $\mathrm{S}$, et al. Serologically silent hepatitis B virus coinfection in patients with hepatitis $\mathrm{C}$ virus-associated chronic liver disease: clinical and virological significance. J Med Virol. 1999;58:201-7.

21. El-Sherif A, Abou-Shady M, Abou-Zeid H, Elwassief A, Elbahrawy A, Ueda Y, et al. Antibody to hepatitis B core antigen as a screening test for occult hepatitis B virus infection in Egyptian chronic hepatitis C patients. J Gastroenterol. 2009;44:359-64.

22. Torbenson M, Kannangai R, Astemborski J, Strathdee SA, Vlahov D and Thomas DL. High prevalence of occult hepatitis B in Baltimore injection drug users. Hepatology. 2004;39:51-7.

23. El-Shaarawy A, Abdel Aziz M, Abdel Rahman S, Rageh E, ElSaharnouby A. HCV Genotype and "Silent" HBV coinfection: Two main risk factors for a more severe liver disease. Tanta Medi Sci J. 2007; 2:15-26.

24. Hassan ZK, Hafez MM, Mansor TM and Zekri AR. Occult HBV infection among Egyptian hepatocellular carcinoma patients. Virol J. 2011;8:90.

25. Selim HS, Abou-Donia HA, Taha HA, El Azab GI and Bakry AF. Role of occult hepatitis B virus in chronic hepatitis C patients with flare of liver enzymes. Eur J Intern Med. 2011;22:187-90.

26. Shih CM, Lo SJ, Miyamura T, Chen SY and Lee YH. Suppression of hepatitis B virus expression and replication by hepatitis C virus core protein in HuH-7 cells. J Virol. 1993;67:5823-32.

27. Dumoulin FL, von dem Bussche A, Li J, Khamzina L, Wands JR, Sauerbruch T, et al. Hepatitis C virus NS2 protein inhibits gene expression from different cellular and viral promoters in hepatic and nonhepatic cell lines. Virology. 2003;305:260-6.

28. Guido M, Thung SN, Fattovich G, Cusinato R, Leandro G, Cecchetto A, et al. Intrahepatic expression of hepatitis B virus antigens: effect of hepatitis C virus infection. Mod Pathol. 1999;12:599-603.

29. De Maria N, Colantoni A, Friedlander L, Leandro G, Idilman R, Harig J, et al. The impact of previous HBV infection on the course of chronic hepatitis C. Am J Gastroenterol. 2000;95:3529-36.

30. Pontisso P, Gerotto M, Ruvoletto M, Fattovich G, Chemello L, Tisminetzky $\mathrm{S}$, et al. Hepatitis $\mathrm{C}$ genotypes in patients with dual hepatitis B and C virus infection. J Med Virol. 1996;48:157-60.

31. Rodriguez-Inigo E, Bartolome J, Ortiz-Movilla N, Platero C, Lopez-Alcorocho JM, Pardo M, et al. Hepatitis C virus (HCV) and hepatitis B virus (HBV) can coinfect the same hepatocyte in the liver of patients with chronic HCV and occult HBV infection. J Virol. 2005;79:15578-81.

32. Gaeta GB, Stornaiuolo G, Precone DF, Lobello S, Chiaramonte M, Stroffolini T, et al. Epidemiological and clinical burden of chronic hepatitis B virus/hepatitis $\mathrm{C}$ virus infection. A multicenter Italian study. J Hepatol. 2003;39:1036-41.

33. Castillo I, Rodriguez-Inigo E, Lopez-Alcorocho JM, Bartolome J, Pardo M and Carreno V. Comparative study on the clinical and virological characteristics among patients with single occult hepatitis B virus (HBV), single occult hepatitis C virus (HCV) and occult HBV and HCV dual infection. J Med Virol. 2007;79:236-41. 
34. Zignego AL, Fontana R, Puliti S, Barbagli S, Monti M, Careccia $\mathrm{G}$, et al. Relevance of inapparent coinfection by hepatitis $\mathrm{B}$ virus in alpha interferon-treated patients with hepatitis $\mathrm{C}$ virus chronic hepatitis. J Med Virol. 1997;51:313-8.

35. Fujiwara K, Tanaka Y, Orito E, Ohno T, Kato T, Sugauchi F, et al. Lack of association between occult hepatitis B virus DNA viral load and aminotransferase levels in patients with hepatitis $\mathrm{C}$ virus-related chronic liver disease. J Gastroenterol Hepatol. 2004;19:1343-7.

36. Kannangai R, Vivekanandan P, Netski D, Mehta S, Kirk GD, Thomas DL, et al. Liver enzyme flares and occult hepatitis B in persons with chronic hepatitis C infection. J Clin Virol. 2007;39:101-5.

37. Silva C, Goncales NS, Pereira JS, Escanhoela CA, Pavan MH and Goncales FL, Jr. The influence of occult infection with hepatitis $\mathrm{B}$ virus on liver histology and response to interferon treatment in chronic hepatitis C patients. Braz J Infect Dis. 2004;8:431-9.

38. Torbenson M, Kannangai R, Astemborski J, Strathdee SA, Vlahov D and Thomas DL. High prevalence of occult hepatitis B in Baltimore injection drug users. Hepatology. 2004;39:51-7.

39. Kazemi-Shirazi L, Petermann D and Muller C. Hepatitis B virus DNA in sera and liver tissue of HBsAg negative patients with chronic hepatitis C. J Hepatol. 2000;33:785-90.

40. Nirei K, Kaneko M, Moriyama M, Arakawa Y. The clinical features of chronic hepatitis $\mathrm{C}$ are not affected by the coexistence of hepatitis B virus DNA in patients negative for hepatitis B surface antigen. Intervirology. 2000;43:95-101.

41. Stransky J, Malina L, Cieslarova B, Stríteský J, Pùtová I, Horák J. Overt and hidden co-infection with hepatitis B and C viruses in chronic liver disease and porphyria cutanea tarda. Acta Virol. 2000;44:23-8.

42. Chemin I, Zoulim F, Merle P, Arkhis A, Chevallier M, Kay A, et al. High incidence of hepatitis B infections among chronic hepatitis cases of unknown aetiology. J Hepatol. 2001;34:447-54.

43. Cacciola I, Pollicino T, Squadrito G, Cerenzia G, Orlando ME, Raimondo G. Occult hepatitis B virus infection in patients with chronic hepatitis C liver disease. N Engl J Med. 1999;341:22-6.

44. Mrani S, Chemin I, Menouar K, Guillaud O, Pradat P, Borghi G, et al. Occult HBV infection may represent a major risk factor of non-response to antiviral therapy of chronic hepatitis C. $J M$ Virol. 2007;79:1075-81.

45. Marzouk, M S. The Effect of Occult Hepatitis (B) Virus Infection on Morbidity of Chronic Hepatitis (C) Liver Disease. Thesis (M.Sc). Dept. of Internal Medicine, Faculty of Medicine, Assiut University, Egypt, 2003. Available online at Envir. Encyclopedia Ass. Univ., 2007: http://www.aun.edu.eg/aun-2006/med-m2003.html.

46. Sagnelli, E, Imparato M, Coppola N, Pisapia R, Sagnelli C, Messina V, et al. Diagnosis and Clinical Impact of Occult Hepatitis B Infection in Patients with Biopsy Proven Chronic Hepatitis C: A Multicenter Study. J Med Virol. 2008;80:1547-53.

47. Zignego A, Fontana R, Puliti S, Barbagli S, Monti M, Careccia G, et al. Impaired response to alpha interferon in patients with an inapparent hepatitis B and hepatitis C virus coinfection. Arch Virol. 1997;142:535-44.

48. Emara MH, Radwan MI. Successful treatment of activated occult hepatitis B in a non-responder chronic hepatitis C patient. Virol
J. 2011;8:518.

49. Zekri AR, Hafez MM, Bahnassy AA, Hassan ZK, Mansour T, Kamal MM, et al. Genetic profile of Egyptian hepatocellularcarcinoma associated with hepatitis C virus Genotype 4 by $15 \mathrm{~K}$ cDNA microarray: preliminary study. BMC Res Notes. 2008;1:106

50. Kamal A, Badran H, Rewisha E, El-Said H, Ghoneim E, Hassouna $\mathrm{M}$, et al. Occult hepatitis $\mathrm{B}$ in chronic liver disease and hepatocellular carcinoma patients. Liver Int. 2006;26:52.

51. Abu El-Makarem M, Abd-Elhamid M, Abdaleem A, Ali A, Shatat M, Sayed D, et al. Prevalence of Occult hepatitis B virus infection in hemodialysis patients from Egypt: with or without hepatitis C virus infection. Hepat Mon. 2012;12:253-8.

52. Tabor E, Hoofnagle J, Smallwood L, Drucker JA, PinedaTamondong GC, Ni LY, et al. Studies of donors who transmit posttransfusion hepatitis. Transfusion. 1979;19:725-31.

53. Thiers V, Nakajima E, Kremsdorf D, Mack D, Schellekens H, Driss F, et al. Transmission of hepatitis B from hepatitis-Bseronegative subjects. Lancet. 1988;2:1273-6.

54. Allain JP. Occult hepatitis B virus infection. Transfus Clin Biol. 2004;11:1825.

55. Assem A, Abou-shady M, El-Hiatmy M, El-Bahrawy A, Motawea E, Abd El-Halim A. Evaluation of hepatitis B core antibody in blood screening for hepatitis B infection. Liver Int. 2006;26:56.

56. El-Zayadi AR, Ibrahim EH, Badran HM, Saeid A, Moneib NA, Shemis MA, et al. Anti-HBc screening in Egyptian blood donors reduces the risk of hepatitis B virus transmission. Transfus Med. 2008;18:55-61.

57. Elghannam DM, Aly RM, Goda EF, Eltoraby EE, Farag RE. Clinical significance of antibody to hepatitis B core antigen in multitransfused hemodialysis patients. Asian J Transfus Sci. 2009;3:14-7.

58. Rodriguez-Torres M, Gonzalez-Garcia J, Brau N, Solá R, Moreno S, Rockstroh J, et al. Occult Hepatitis B Virus Infection in The Setting of Hepatitis C Virus (HCV) and Human Immunodeficiency Virus (HIV) Co-infection: Clinically Relevant or a Diagnostic Problem? J Medical Virol. 2007;79:694-700.

59. Said ZN, El-Sayed MH, El-Bishbishi IA, El-Fouhil DF, AbdelRheem SE, El-Abedin MZ, et al. High prevalence of occult hepatitis B in hepatitis C-infected Egyptian children with haematological disorders and malignancies. Liver Int. 2009;29:518-24.

60. Ismail H, Soliman M, Ismail N. Occult hepatitis B virus infection in Egyptian hemodialysis patients with or without hepatitis C virus infection. Pathol Lab Med Int. 2010;2:113-20.

61. Manzano-Alonso ML and Castellano-Tortajada G. Reactivation of hepatitis B virus infection after cytotoxic chemotherapy or immunosuppressive therapy. World J Gastroenterol. 2011;17:1531-7.

62. Lalazar G, Rund D and Shouval D. Screening, prevention and treatment of viral hepatitis B reactivation in patients with haematological malignancies. Br J Haematol. 2007;136:699-712.

63. Raimondo G, Navarra G, Mondello S, Costantino L, Colloredo G, Cucinotta E, et al. Occult hepatitis B virus in liver tissue of individuals without hepatic disease. J Hepatol. 2008;48:743-6.

64. Raimondo G, Pollicino T, Cacciola I and Squadrito G. Occult hepatitis B virus infection. J Hepatol. 2007;46:160-70. 
65. Prieto M, Gomez MD, Berenguer M, Cordoba J, Rayon JM, Pastor M, et al. De novo hepatitis B after liver transplantation from hepatitis B core antibody-positive donors in an area with high prevalence of anti-HBc positivity in the donor population. Liver Transpl. 2001;7:51-8.

66. Munoz S. Use of hepatitis B core antibody-positive donors for liver transplantation. Liver Transpl. 2002;8:82-7.

67. Strasser SI and McDonald GB. Hepatitis viruses and hematopoietic cell transplantation: A guide to patient and donor management. Blood. 1999;93:1127-36.

68. Iwai K, Tashima M, Itoh M, Okazaki T, Yamamoto K, Ohno H, et al. Fulminant hepatitis $\mathrm{B}$ following bone marrow transplantation in an HBsAg-negative, HBsAb-positive recipient; reactivation of dormant virus during the immunosuppressive period. Bone Marrow Transplant. 2000;25:105-8.

69. Llovet JM, Burroughs A and Bruix J. Hepatocellular carcinoma. Lancet. 2003;362:1907-17.

70. Pollicino T, Squadrito G, Cerenzia G, Cacciola I, Raffa G, Craxi A, et al. Hepatitis B virus maintains its pro-oncogenic properties in the case of occult HBV infection. Gastroenterology.
2004;126:102-10.

71. Ding X, Park YN, Taltavull TC, Thung SN, Jin X, Jin Y, et al. Geographic characterization of hepatitis virus infections, genotyping of hepatitis B virus, and p53 mutation in hepatocellular carcinoma analyzed by in situ detection of viral genomes from carcinoma tissues: comparison among six different countries. Jpn J Infect Dis. 2003;56:12-8.

72. Abd El monem E, Fawzy A, Ghaleb FM, El Taher S, Abo Al Ela AM, Farag MA. The Relationship between hepatitis B Virus-X Gene, P53 gene mutation and Hepatocellular Carcinoma in HBs Ag Negative Patients with and without HCV Infection. Australian J Basic Applied Sci. 2010;4:79-88.

73. Andrisani $\mathrm{OM}$ and Barnabas $\mathrm{S}$. The transcriptional function of the hepatitis B virus X protein and its role in hepatocarcinogenesis (Review). Int J Oncol. 1999;15:373-9.

74. Chen $\mathrm{CH}$, Changchien CS, Lee CM, Tung WC, Hung CH, Hu $\mathrm{TH}$, et al. A study on sequence variations in pre-S/surface, $\mathrm{X}$ and enhancer II/core promoter/precore regions of occult hepatitis B virus in non-B, non-C hepatocellular carcinoma patients in Taiwan. Int J Cancer. 2009;125:621-9. 